Плодоводство и виноградарство Юга России № 59(5), 2019 г.

УДК 544.723:543.42:546.33:546.41:546.723

UDC 544.723:543.42:546.33:546.41:546.723

DOI 10.30679/2219-5335-2019-5-59-144-154

DOI 10.30679/2219-5335-2019-5-59-144-154

ОСВЕТЛЕНИЕ

И СТАБИЛИЗАЦИЯ ВИН

С ПОМОЩЬЮ ОТЕЧЕСТВЕННЫХ БЕНТОНИТОВ

Агеева Наталья Михайловна

д-р техн. наук, профессор

главный научный сотрудник

научного центра «Виноделие»

e-mail: ageyeva@inbox.ru

Киян Андрей Тимофеевич

д-р с.-х. наук

e-mail: Andrey Kiyan@yandex.ru

Федеральное государственное

бюджетное научное учреждение

«Северо-Кавказский федеральный

научный иентр садоводства,

виноградарства, виноделия»,

Краснодар, Россия

Панарин Вячеслав Михайлович

коммерческий директор

ООО «БИОРОСТ» Москва, Россия

Ведущей в России компанией

по переработке глинистых минералов

(бентонитов) является ООО «БИОРОСТ», продукция которой - винобент и бентовин пользуется спросом на рынке алкогольной продукции. Ведутся разработки бентонита BentoVinum Gold, Республика Казахстан. Ранее проведенные исследования показали целесообразность применения бентонитов BentoVinum Gold, бентовин, винобент и активит (контроль) - для осветления белых и красных столовых виноматериалов. Цель настоящей работы - установить оптимальные технологические дозировки бентонитов для обработки вин различных типов и оценить стабильность (розливостойкость) обработанных вин. В качестве объектов исследований

\section{THE CLARIFICATION AND THE STABILIZATION OF WINES USING THE DOMESTIC BENTONITES}

\author{
Ageyeva Natalia Mikhailovna \\ Dr. Sci. Tech., Professor \\ Chief Research Associate \\ of SC «Wine-making» \\ e-mail: ageyeva@inbox.ru
}

Kiyan Andrey Timofeevich

Dr. Sci. Agr.

e-mail: Andrey Kiyan@yandex.ru

\section{Federal State Scientific}

Budget Institution

"North-Caucasian Federal

Scientific Center of Horticulture,

Viticulture, Winemaking»,

Krasnodar, Russia

Panarin Vyacheslav Mikhaylovich

Business manager

«BIOROST»LLS, Moskov, Russia

The leading company for the processing of clay minerals (bentonites) in Russia is BIOROST LLC, whose products vinoobent and bentovin - are in demand in the market for alcoholic products.

The development is carried out of bentonite BentoVinum Gold, Republic of Kazakhstan. Earlier studies have shown the expendiency of bentonites using - BentoVinum Gold, bentovin, vinobet and activite (control) clarification the white and red table wine materials. The purpose of this work is to establish the optimal technological dosages of bentonites for processing wines of various types and to assess the stability (resistance to bottle) of the processed wines. Untreated white 
использованы необработанные белый (Совиньон блан) и красный

(Каберне-Совиньон) столовые виноматериалы. Обработку проводили $10 \%$-ными вино-водными суспензиями бентонитов или совместно с $1 \%$-ным раствором желатина. Дозировка бентонитов варьировала от 1 до 5 г/дм ${ }^{3}$, желатина от 5 до 200 мг/дм³ ${ }^{3}$ Установлено, что применение бентонита BentoVinum Gold обеспечило кристальную прозрачность виноматериалов при наименьших технологических дозировках и минимальных объемах гущевых осадков. Высокую осветляющую способность проявил бентовин, особенно с размером частиц минерала менее 0,05 мм. При совместной обработке виноматериалов бентонитом и желатином отмечено уменьшение дозировок обоих сорбентов. Установлены оптимальные дозировки исследуемых бентонитов при обработке белого и красного столовых виноматериалов. Полученные результаты свидетельствуют о высокой стабилизирующей способности комплексной обработки столовых виноматериалов бентонитом BentoVinum Gold: виноматериалы длительное время сохраняли розливостойкость, образцы красных виноматериалов были более устойчивы к коллоидным помутнениям. При использовании бентовина и винобента стабильность вина сохранялась в течение 6-8 месяцев. Исследуемые бентониты рекомендованы для применения в российском виноделии с целью замены импортных аналогов.

Ключевые слова: БЕНТОНИТ, БЕЛЫЕ И КРАСНЫЕ СТОЛОВЫЕ ВИНОМАТЕРИАЛЫ, ОСВЕТЛЕНИЕ, СТАБИЛИЗАЦИЯ, ОПТИМАЛЬНЫЕ ТЕХНОЛОГИЧЕСКИЕ ДОЗИРОВКИ
(Sauvignon blanc) and red (Cabernet-Sauvignon) table wine materials were used as objects of research. The treatment was carried out with $10 \%$ wine-water suspensions of bentonites or join with a $1 \%$ solution of gelatin. The dosage of bentonites ranged from 1 to $5 \mathrm{~g} / \mathrm{dm}^{3}$, gelatin from 5 to $200 \mathrm{mg} / \mathrm{dm}^{3}$. It has been established that the use of BentoVinum Gold bentonite provided the crystal clearness of wine materials with the smallest technological dosages and minimum volumes of thick sediments. Bentovin showed a high lightening ability, especially with a mineral particle size of less than $0.05 \mathrm{~mm}$. When join-processing wine materials with bentonite and gelatin, a decrease in dosages of both sorbents was observed. The optimum dosages of the studied bentonites were established when processing white and red table wine materials.

The obtained results testify to the high stabilizing ability of complex processing of table wine materials with BentoVinum Gold bentonite: wine materials have been resistant to bottle for a long time, the samples of red wine materials were more resistant to colloid turbidity. When using bentovin and vinobent, the stability of the wine was maintained for 6-8 months. The studied bentonites are recommended for use in Russian wine-making in order to replace imported analogues.

Key words: BENTONIT, WHITE AND RED TABLE WINE MATERIALS, CLARIFICATION, STABILIZATION, OPTIMUM TECHNOLOGICAL DOSES

Введение. Одним из надёжных средств осветления и стабилизации винопродукции с давних лет является её обработка суспензиями бентонитов 
(глинистых минералов) $[1,2,3]$. Эффективная сорбция бентонитами высокомолекулярных соединений, микроорганизмов и прочих мутящих частиц делает их практически незаменимыми в целях обеспечения розливостойкости продукции, а также при подготовке виноматериалов к шампанизации [4, 5, 6]. Бентониты по-прежнему широко применяют как в России, так и в других винодельческих регионах мира для профилактики коллоидных помутнений, вызванных белками, полифенолами, полисахаридами и их комплексами [7, 8, 9].

Анализ литературных источников свидетельствует о том, что суспензии бентонитов способны проявлять свои лучшие качества как самостоятельно, так и в комплексе с другими сорбентами, в том числе с желатином, флоккулянтами, активированными углями и пр., при этом отмечается снижение уровня окисленности, гармонизация аромата, уменьшение концентрации поверхностно-активных веществ, общего экстракта $[10,11,12]$.

Поэтому многие зарубежные фирмы, специализирующиеся на производстве вспомогательных материалов для винодельческой промышленности, разработали и выпускают комплексные сорбенты, в состав которых, кроме глинистого минерала, входят поливинилпирролидон, желатин, танин и другие соединения.

Оптимальные технологические дозировки бентонитов варьируют в широких пределах и зависят не только от химического состава обрабатываемого продукта, но и от строения, сорбционной и коагуляционной способности самих минералов $[13,14,15]$. Предпочтение отдается тем сорбентами, которые, обеспечивая лучшую прозрачность обрабатываемого вина, позволяют достичь его устойчивости против коллоидных помутнений при меньших технологических дозировках.

В связи с этим поиск эффективных отечественных бентонитов, и оптимизация их дозировок является актуальной задачей. 
Плодоводство и виноградарство Юга России № 59(5), 2019 г.

Цель работы - установление оптимальных технологических дозировок бентонитовых глинопорошков (бентонитов) ООО «БИОРОСТ» (г.Москва) для осветления и стабилизации винопродукции.

Объекты и методы исследований. В качестве объектов исследования использовали 10 \%-ные суспензии кальций-натриевых бентонитов ООО «БИОРОСТ

- BentoVinum Gold, Таганское месторождение, Республика Казахстан, горизонт 14 , размер частиц менее 0,07 и менее 0,05 ;

- бентовин, Даш-Салахнинское месторождение (республика Азербайджан), размер частиц менее 0,07 и менее 0,05 ;

- винобент, месторождение «10-й хутор», Республика Хакасия, размер частиц менее 0,07 и менее 0,05 .

В качестве контроля использовали бентонит активит, производство Ербсле Гайзенхайм, Германия. Суспензии минералов готовили по общепринятой технологии [13].

Исследования проведены на белом (Совиньон блан) и красном (Каберне-Совиньон) столовых виноматериалах. Оптимальные технологические дозировки каждого из бентонитов определяли путем пробной обработки виноматериалов, варьируя их дозировки от 1 до 5 г/дм³. При комплексной технологической обработке количество вносимого раствора желатина изменяли от 5 до 200 мг/дм³ с шагом 20 мг/дм³

Физико-химические показатели виноматериалов определяли по методикам $[16,17]$ и действующим стандартам. Для характеристики мутности применяли турбидиметр Sigrist (США). Величину мутности выражали в условных единицах. Для оценки розливостойкости (стабильности) виноматериала применяли методики по [13]. Кроме того, обработанный виноматериал выдерживали в провокационных условиях (температура $22-25{ }^{\circ} \mathrm{C}$ ) и наблюдали за изменением его прозрачности. 
Плодоводство и виноградарство Юга России № 59(5), 2019 г.

Обсуждение результатов. Оптимальные технологические дозировки сорбентов при обработке белого столового виноматериала, обеспечившее его качественную прозрачность, представлены в таблице 1.

Таблица 1 - Оптимальные технологические дозировки сорбентов при обработке белого столового виноматериала

\begin{tabular}{|c|c|c|c|}
\hline \multirow[b]{2}{*}{ Наименование бентонита } & \multirow{2}{*}{$\begin{array}{c}\text { Обработка } \\
\text { бентонитом, } \\
\text { г/дм } \\
\end{array}$} & \multicolumn{2}{|c|}{ Комплексная обработка } \\
\hline & & $\begin{array}{c}\text { бентонит, } \\
\text { г/дм }^{3}\end{array}$ & $\begin{array}{c}\text { желатин, } \\
\text { мг/дм }\end{array}$ \\
\hline $\begin{array}{l}\text { BentoVinum Gold, paзмер } \\
\text { частиц менеe } 0,05\end{array}$ & 1,0 & 0,5 & 25 \\
\hline $\begin{array}{l}\text { BentoVinum Gold, размер частиц } \\
\text { менеe } 0,07\end{array}$ & 1,0 & 0,5 & 25 \\
\hline $\begin{array}{l}\text { Бентовин, размер частиц } \\
\text { менее } 0,05\end{array}$ & 1,0 & 0,5 & 25 \\
\hline $\begin{array}{l}\text { Бентовин, размер частиц } \\
\text { менее } 0,07\end{array}$ & 1,5 & 1,0 & 50 \\
\hline $\begin{array}{l}\text { Винобент, размер частиц } \\
\text { менее } 0,05\end{array}$ & 1,5 & 1,0 & 50 \\
\hline $\begin{array}{l}\text { Винобент, размер частиц } \\
\text { менее } 0,07\end{array}$ & 2,0 & 1,5 & 50 \\
\hline Активит, контроль & 1,0 & 1,0 & 50 \\
\hline
\end{tabular}

Анализ экспериментальных данных свидетельствует о высокой осветляющей способности бентонита BentoVinum Gold, применение которого обеспечило кристальную прозрачность (мутность 38 усл. ед.) виноматериала при наименьших технологических дозировках и минимальных объёмах гущевых осадков $(6,7$ \%). Следует отметить, что при внесении минерала в виноматериал сначала образовалась мутная вино-бентонитовая суспензия. Агрегирование и последующая седиментация коллоидных частиц протекали медленно: первые признаки формирования осадка отмечены через два часа после обработки. Полное осветление достигнуто через 8 часов.

При комплексной обработке виноматериала (вносили желатин, спустя 1,5-2 часа - бентонит) оптимальные результаты (мутность 38-40 усл. ед.) получены при тех же технологических дозировках. Это свидетельствует о высокой сорбционной способности минерала к мутящим и высокомолекулярным соединениям вина и согласуется с литературными данными $[2,18,19]$. 
Плодоводство и виноградарство Юга России № 59(5), 2019 г.

При использовании бентонита BentoVinum Gold степень дисперсности (размер частиц) минерала не оказала существенного влияния на его оптимальные технологические дозировки и осветляющую способность. По степени осветления получены результаты, идентичные контрольному варианту - активиту (Германия), но при меньшей дозировке желатина.

Высокую осветляющую способность показал бентовин (мутность 39-40 усл. ед.), особенно с размером частиц менее 0,05 мм. Увеличение размера частиц привело к повышению дозировки как самого бентовина, так и желатина, использованного при комплексной обработке. Ориентируясь на литературные данные [20,21], можно считать, что при размере частиц менее 0,05 мм в вино-водной суспензии минерал диспергирует до элементарных пакетов, что в значительной степени увеличивает его активную поверхность, на которой протекает взаимодействие с компонентами вина.

В сравнении с препаратом BentoVinum Gold осветление виноматериала бентовином протекало быстрее: в течение 8 часов образовались плотные осадки, при этом мутность виноматериала варьировала от 43 до 46 усл. ед.

Оптимальные технологические дозировки винобента были несколько выше в сравнении с другими минералами и варьировали от 1 до 2 г/дм³ Уменьшение размера частиц, а также внесение желатина способствовали улучшению качества обработки (мутность 40-42 усл. ед.) и снижению технологической дозировки винобента, что связано с взаимодействием желатина с танинами вина, образованием и седиментацией их комплексов $[22,23]$.

При обработке красного столового виноматериала оптимальные технологические дозировки минералов и желатина были выше (табл. 2). Это связано с наличием высоких концентраций фенольных соединений и их комплексов с компонентами вина, замедляющих и затрудняющих взаимодействие между одноименно заряженными частицами бентонитов и полифенолов. Осветление виноматериала протекало медленно всеми использо- 
ванными бентонитами, особенно BentoVinum Gold. Полное осветление экспериментальных образцов виноматериалов было достигнуто только через сутки. Мутность обработанных красных виноматериалов изменялась от 72 (BentoVinum Gold) до 85 усл. ед. (винобент). При комплексной обработке еe значение уменьшилось и составило 70-78 усл. ед.

Таблица 2 - Оптимальные технологические дозировки сорбентов при обработке красного столового виноматериала

\begin{tabular}{|l|c|c|c|}
\hline \multirow{2}{*}{ Наименование бентонита } & $\begin{array}{c}\text { Обработка } \\
\text { бентонитом, } \\
\text { г/дм }\end{array}$ & $\begin{array}{c}\text { Кентонит, } \\
\text { Г/дм }\end{array}$ & $\begin{array}{c}\text { желатин, } \\
\text { мг/дм }^{3}\end{array}$ \\
\hline $\begin{array}{l}\text { BentoVinum Gold, размер частиц } \\
\text { менее 0,05 }\end{array}$ & 1,5 & 1,0 & 25 \\
\hline $\begin{array}{l}\text { BentoVinum Gold, размер частиц } \\
\text { менее 0,07 }\end{array}$ & 1,5 & 1,0 & 25 \\
\hline $\begin{array}{l}\text { Бентовин, размер частиц } \\
\text { менее 0,05 }\end{array}$ & 2,0 & 1,5 & 50 \\
\hline $\begin{array}{l}\text { Бентовин, размер частиц } \\
\text { менее 0,07 }\end{array}$ & 2,5 & 2,0 & 50 \\
\hline $\begin{array}{l}\text { Винобент, размер частиц } \\
\text { менее 0,05 }\end{array}$ & 3,0 & 2,0 & 50 \\
\hline $\begin{array}{l}\text { Винобент, размер частиц } \\
\text { менее 0,07 }\end{array}$ & 3,0 & 1,5 & 50 \\
\hline Активит, контроль & 2,5 & 1,0 & 50 \\
\hline
\end{tabular}

Полученные результаты (табл. 2) показали, что оптимальные технологические дозировки бентонитов составляли:

- BentoVinum Gold - 1,0-1,5 г/дм ${ }^{3}$ при внесении желатина в количестве $25 \mathrm{мг} /$ дм$^{3}$;

- бентовин - 1,5-2,5 г/дм³ при внесении желатина в количестве $50 \mathrm{мг/дм^{3 } ;}$

- винобент - 1,5-3,0 г/дм ${ }^{3}$ при внесении желатина в количестве $25-50$ мг/дм ${ }^{3}$;

- активит (контроль) - 1,0-2,5 г/дм³ при внесении желатина в количестве 50 мг/дм ${ }^{3}$.

Важнейшим результатом технологических обработок виноматериалов оклеивающими веществами является достижение розливостойкости, то есть 
Плодоводство и виноградарство Юга России № 59(5), 2019 г.

устойчивости к коллоидным помутнениям, обусловленным наличием высоких концентраций высокомолекулярных компонентов и их комплексов. Оценка розливостойкости вин путём тестирования показала устойчивость обработанных виноматериалов к коллоидным помутнениям. Более объективные результаты получены при длительном хранении виноматериалов. Полученные экспериментальные данные свидетельствуют о высокой стабилизирующей способности комплексной обработки белых и красных столовых виноматериалов бентонитом BentoVinum Gold: по истечении 10 месяцев с момента обработки и по настоящее время виноматериалы сохраняли розливостойкость. При этом образцы красных виноматериалов были более устойчивы к коллоидным помутнениям (табл. 3).

Таблица 3 - Продолжительность стабильности (месяц) виноматериалов при обработке оптимальными технологическими дозировками сорбентов

\begin{tabular}{|c|c|c|}
\hline Наименование бентонита & $\begin{array}{c}\text { Обработка } \\
\text { бентонитом }\end{array}$ & $\begin{array}{c}\text { Комплексная } \\
\text { обработка }\end{array}$ \\
\hline \multicolumn{3}{|c|}{ Белый столовый виноматериал } \\
\hline BentoVinum Gold, размер частиц менее 0,05 & 8,5 & более $10^{*}$ \\
\hline BentoVinum Gold, размер частиц менее 0,07 & 8,5 & более $10^{*}$ \\
\hline Бентовин, размер частиц менее 0,05 & 7,5 & 9,5 \\
\hline Бентовин, размер частиц менее 0,07 & 7,0 & 8,4 \\
\hline Винобент, размер частиц менее 0,05 & 6,5 & 8,0 \\
\hline Винобент, размер частиц менее 0,07 & 6,0 & 7,5 \\
\hline Активит, контроль & 7,5 & более $10^{*}$ \\
\hline \multicolumn{3}{|c|}{ Красный столовый виноматериал } \\
\hline BentoVinum Gold, размер частиц менее 0,05 & 9,0 & более $10^{*}$ \\
\hline Gold, размер частиц менее 0,07 & 9,0 & более $10^{*}$ \\
\hline Бентовин, размер частиц менее 0,05 & 9,0 & более $10^{*}$ \\
\hline Бентовин, размер частиц менее 0,07 & 9,0 & более $10^{*}$ \\
\hline Винобент, размер частиц менее 0,05 & 6,5 & 8,0 \\
\hline Винобент, размер частиц менее 0,07 & 5,5 & 7,5 \\
\hline Активит, контроль & 9,0 & более $10^{*}$ \\
\hline
\end{tabular}

*Примечание: наблюдение продолжается, виноматериал остаётся стабильным 
В большинстве обработанных белых столовых виноматериалов через полгода хранения отмечено появление легкой опалесценции, а через 7-8 месяцев - образование налета, в состав которого входили катионы кальция и полисахариды. Аналогичные результаты получены при использовании контрольного бентонита - активита.

\section{Bbывды. Применение бентонитов российского производства} ООО «БИОрост», обладающих высокой осветляющей и стабилизирующей способностью, позволяет использовать их для обработки вин взамен импортных аналогов.

\section{Литература}

1. Теория и практика виноделия / Ж. Риберо-Гайон, Э. Пейно, П. Риберо-Гайон, П. Сюдро / Под ред. Г. Г. Валуйко. М.: Легкая и пищевая пром-сть, 1981. Т. 4. 416 с.

2. Христюк В.Т. Применение природных минеральных сорбентов для обработки виноградных и плодовых вин. Краснодар: Экоинвест, 2010. 332 с.

3. Агеева Н.М. Стабилизация виноградных вин: теоретические аспекты и практические рекомендации. Краснодар: Просвещение-Юг, 2007. 251 с.

4. Ковалев, Н.Н. Усовершенствование технологии игристых вин с использованием дисперсных минералов: автореф. дисс. ... канд. техн. наук. 05.18.07 / Ковалёв Николай Николаевич. Киев, 2000. 20 с.

5. Jaeckels, N.; Tenzer, S.; Meier, M.; Will, F.; Dietrich, H.; Decker, H. and Fronk, P. (2017) Influence of bentonite fining on protein composition in wine. LWT -- Food Science and Technology 75:335-343.

6. Martínez-Lapuente, L.; Guadalupe, Z.; Ayestaran, B.; OrtegaHeras, M.; Perez-Magarino, S. Sparkling wine produced from alternative varieties: sensory attributes and evolution of phenolics during winemaking and aging. Am. J. Enol. Vitic. 2013, 64 (1), 39-49.

7. Achaerandio, I., Pachova, V., Guell, C. \& Lopez, F. (2001). Proteinadsorption by bentonite in a white wine model solution: eff ect of protein molecular weight and ethanol concentration. AmericanJournal of Enology and Viticulture, 52, 122 - 126.

8. Effect of using bentonite during fermentation on proteinstabilisation and sensory properties of white wine. Eugenio Lira,Fernando N. Salazar, Juan J. Rodriguez-Bencomo, Simone Vincenzi, Andrea Curioni. - International Journal of Food Science and Technology 2014, 49, 1070-1078

9. Fernando N Salazar, Elizabeth Joy Waters. The effect of bentonite fining at different stages of white winemaking on protein stability.- Australian Journal of Grape and Wine Research 17(2):280 - 284 - March 2011

10. Robinson J. The Oxford Companion to Wine. Third Edition. p. 508 Oxford University Press.- 2006 ISBN 0-19-860990-6

11. Harbertson, J.F., E.A. Picciotto, and D.O. Adams. 2003. Measuring polymeric pig- 
ments in grape berry extracts and wines using a protein precipitation assay combined with bisulfite bleaching. American Journal of Enology and Viticulture 54:301-306.

12. Lambri, M.; Dordoni, R.; Silva, A. and De Faveri, D.M. (2010) Effect of bentonite fining on odouractive compounds in two different white wine styles. American Journal of Enology and Viticulture 61(2):225-233

13. Сборник основных правил, технологических инструкций и нормативных материалов по производству винодельческой продукции. М.: Пищепромиздат, 1998. $242 \mathrm{c}$.

14. Агеева Н.М. Научно-практические рекомендации по применению вспомогательных материалов с целью обеспечения розливостойкости вин. Краснодар: Просвещение-Юг, 2013. 74 с.

15. Обожин А.Н., Агеева Н.М., Марковский М.Г. Влияние комплексных минеральных сорбентов на катионный состав вин // Известия Вузов. Пищевая технология. 2003. № 5-6. С. 34-42.

16. Методы технохимического контроля в виноделии / Под ред. В.Г. Гержиковой. Симферополь: Таврида, 2002. 260 с.

17. Якуба Ю.Ф. Применение капиллярного электрофореза для определения катионов в винах специальных технологий // Заводская лаборатория. Диагностика материалов. 2006. Т. 72. № 4. С.11-15.

18. Covacia E., Ducab G., Sturzac R. The influence of applied stabilization method on the crystalline stability of young white wines / Chem. J. Mold. 2013, 8(2), 73-77

19. Development of alternative bentonite treatments for heat-unstable white wine /Richard Anthony Muhlack, BE (Chem) Hons/ School of Chemical Engineering Faculty of Engineering, Computer and Mathematical Sciences. The University of Adelaide.- 2006. - p.139

20. Соколов, В.Н. Глинистые породы и их свойства / Соросовский образовательный журнал. 2000. Т. 6. № 9. С. 59-65.

21. Тарасевич Ю.И. Строение и химия поверхности слоистых силикатов. Киев: Наукова думка, 1988. 242 с.

22. Pavličević J., Špírková M., Bera O., Jovičić M., Mészáros K. The influence of bentonite and montmorillonite addition on thermal decomposition of novel polyurethane/organoclay nanocomposites. Macedonian Journal of Chemistry and Chemical Engineerin Vol 32, No 2 (2013), p.319-330.

23. Preparations of gelatin in the wine making / O.O. Chursina, V.G. Gerzhikova, A.M.Balayeva, I.M. Babich // Food and processing industry. - 2004 - № 12 - P. 22-23

\section{References}

1. Teoriya i praktika vinodeliya / Zh. Ribero-Gajon, E. Pejno, P. Ribero-Gajon, P. Syudro / Pod red. G. G. Valujko. M.: Legkaya i pishchevaya prom-st', 1981. T. 4. 416 s.

2. Hristyuk V.T. Primenenie prirodnyh mineral'nyh sorbentov dlya obrabotki vinogradnyh i plodovyh vin. Krasnodar: Ekoinvest, 2010. $332 \mathrm{~s}$.

3. Ageeva N.M. Stabilizaciya vinogradnyh vin: teoreticheskie aspekty I prakticheskie rekomendacii. Krasnodar: Prosveshchenie-Yug, 2007. 251 s.

4. Kovalev, N.N. Usovershenstvovanie tekhnologii igristyh vin s ispol'zovaniem dispersnyh mineralov: avtoref. diss. ... kand. tekhn. nauk. 05.18.07 / Kovalyov Nikolaj Nikolaevich. Kiev, 2000. 20 s.

5. Jaeckels, N.; Tenzer, S.; Meier, M.; Will, F.; Dietrich, H.; Decker, H. and Fronk, P. (2017) Influence of bentonite fining on protein composition in wine. LWT - Food Science and Technology 75:335-343. 
6. Martínez-Lapuente, L.; Guadalupe, Z.; Ayestaran, B.; OrtegaHeras, M.; Perez-Magarino, S. Sparkling wine produced from alternative varieties: sensory attributes and evolution of phenolics during winemaking and aging. Am. J. Enol. Vitic. 2013, 64 (1), 39-49.

7. Achaerandio, I., Pachova, V., Guell, C. \& Lopez, F. (2001). Proteinadsorption by bentonite in a white wine model solution: eff ect of protein molecular weight and ethanol concentration. AmericanJournal of Enology and Viticulture, 52, 122 - 126.

8. Effect of using bentonite during fermentation on proteinstabilisation and sensory properties of white wine. Eugenio Lira,Fernando N. Salazar, Juan J. Rodrıguez-Bencomo, Simone Vincenzi, Andrea Curioni. - International Journal of Food Science and Technology 2014, 49, 1070-1078

9. Fernando N Salazar, Elizabeth Joy Waters. The effect of bentonite fining at different stages of white winemaking on protein stability.- Australian Journal of Grape and Wine Research 17(2):280 - 284 - March 2011

10. Robinson J. The Oxford Companion to Wine. Third Edition. p. 508 Oxford University Press.- 2006 ISBN 0-19-860990-6

11. Harbertson, J.F., E.A. Picciotto, and D.O. Adams. 2003. Measuring polymeric pigments in grape berry extracts and wines using a protein precipitation assay combined with bisulfite bleaching. American Journal of Enology and Viticulture 54:301-306.

12. Lambri, M.; Dordoni, R.; Silva, A. and De Faveri, D.M. (2010) Effect of bentonite fining on odouractive compounds in two different white wine styles. American Journal of Enology and Viticulture 61(2):225-233

13. Sbornik osnovnyh pravil, tekhnologicheskih instrukcij i normativnyh materialov po proizvodstvu vinodel'cheskoj produkcii. M.: Pishchepromizdat, $1998242 \mathrm{~s}$.

14. Ageeva N.M. Nauchno-prakticheskie rekomendacii po primeneniyu vspomogatel'nyh materialov s cel'yu obespecheniya rozlivostojkosti vin. Krasnodar: ProsveshchenieYug, 2013. $74 \mathrm{~s}$.

15. Obozhin A.N., Ageeva N.M., Markovskij M.G. Vliyanie kompleksnyh mineral'nyh sorbentov na kationnyj sostav vin // Izvestiya Vuzov. Pishchevaya tekhnologiya. 2003. № 5-6. S. 34-42.

16. Metody tekhnohimicheskogo kontrolya v vinodelii / Pod red. V.G. Gerzhikovoj. Simferopol': Tavrida, 2002. $260 \mathrm{~s}$.

17. Yakuba Yu.F. Primenenie kapillyarnogo elektroforeza dlya opredeleniya kationov v vinah special'nyh tekhnologij // Zavodskaya laboratoriya. Diagnostika mate-rialov. 2006. T. 72. № 4. S.11-15.

18. Covacia E., Ducab G., Sturzac R. The influence of applied stabilization method on the crystalline stability of young white wines / Chem. J. Mold. 2013, 8(2), 73-77

19. Development of alternative bentonite treatments for heat-unstable white wine /Richard Anthony Muhlack, BE (Chem) Hons/ School of Chemical Engineering Faculty of Engineering, Computer and Mathematical Sciences. The University of Adelaide.- 2006. - r.139

20. Sokolov, V.N. Glinistye porody i ih svojstva / Sorosovskij obrazovatel'nyj zhurnal. 2000. T. 6. № 9. S. 59-65.

21. Tarasevich Yu.I. Stroenie i himiya poverhnosti sloistyh silikatov. Kiev: Naukova dumka, 1988. $242 \mathrm{~s}$.

22. Pavličević J., Špírková M., Bera O., Jovičić M., Mészáros K. The influence of bentonite and montmorillonite addition on thermal decomposition of novel polyurethane/organoclay nanocomposites. Macedonian Journal of Chemistry and Chemical Engineerin Vol 32, No 2 (2013), r.319-330.

23. Preparations of gelatin in the wine making / O.O. Chursina, V.G. Gerzhikova, A.M. Balayeva, I.M. Babich // Food and processing industry. - 2004 - № 12 - P. 22-23 